Article

\title{
Impact of Thermal Degradation of Cyanidin-3-O-Glucoside of Haskap Berry on Cytotoxicity of Hepatocellular Carcinoma HepG2 and Breast Cancer MDA-MB-231 Cells
}

\author{
Eric Pace ${ }^{1}$, Yuanyuan Jiang ${ }^{1,2}$, Amy Clemens ${ }^{1}$, Tennille Crossman ${ }^{1}$ \\ and H.P. Vasantha Rupasinghe $1, * \mathbb{D}$ \\ 1 Department of Plant, Food, and Environmental Sciences, Faculty of Agriculture, Dalhousie University, Truro, \\ NS B2N 5E3, Canada; pace.eric.arthur@gmail.com (E.P.); yyjiang@dal.ca (Y.J.); am661344@dal.ca (A.C.); \\ tennille.crossman@dal.ca (T.C.) \\ 2 College of Science, Sichuan Agricultural University, Yaan 625014, China \\ * Correspondence: vrupasinghe@dal.ca; Tel.: +1-902-893-6623; Fax: +1-902-893-1404
}

Received: 14 January 2018; Accepted: 25 January 2018; Published: 27 January 2018

\begin{abstract}
Cyanidin-3-O-glucoside (C3G), the predominant anthocyanin in haskap berries (Lonicera caerulea L.), possesses antioxidant and many other biological activities. This study investigated the impact of temperature and $\mathrm{pH}$ on the degradation of the C3G-rich haskap fraction. The effect of the thermal degradation products on the viability of hepatocellular carcinoma HepG2 and breast cancer MDA-MB-231 cells was also studied in vitro. Using column chromatography, the C3G-rich fraction was isolated from acetone extracts of haskap berries. The C3G stability in these fractions was studied under elevated temperatures $\left(70{ }^{\circ} \mathrm{C}\right.$ and $\left.90{ }^{\circ} \mathrm{C}\right)$ at three different $\mathrm{pH}$ values $(2.5,4$, and 7$)$ by monitoring the concentration of $\mathrm{C} 3 \mathrm{G}$ and its major degradation products, protocatechuic acid (PCA) and phloroglucinaldehyde (PGA), using liquid chromatography mass spectrometry. Significant degradation of C3G was observed at elevated temperatures and at neutral $\mathrm{pH}$. Conversely, the PCA and PGA concentration increased at higher $\mathrm{pH}$ and temperature. Similar to C3G, neutral $\mathrm{pH}$ also has a prominent effect on the degradation of PGA, which is further accelerated by heating. The C3G-rich fraction exhibited dose-dependent inhibitory effects on cell metabolic activity when the HepG2 cells were exposed for $48 \mathrm{~h}$. Interestingly, PGA but not PCA exhibited cytotoxic effects against both MDA-MB-231 and HepG2 cells. The results suggest that thermal food processing of haskap could influence its biological properties due to the degradation of C3G.
\end{abstract}

Keywords: anthocyanin; food processing; antioxidant; cancer; cell viability; phenolic compounds

\section{Introduction}

Haskap (Lonicera caerulea L.) berries, also known as blue honeysuckle and honeyberry, are a relatively new crop in North America. Berries of this genus have been used for medicinal purposes in Russia and some Asian countries for thousands of years [1,2]. There are three major cultivars of this berry being produced in Canada, and they have attracted interest due to their relatively high concentration of health-promoting anthocyanins when compared with other commonly consumed fruit $[1,3,4]$. Many studies have indicated that anthocyanins have the potential to be effective in cancer chemoprevention. Anti-proliferative effects on multiple cancer cell types in vitro, pro-apoptotic effects on cancer cell lines, reduction in inflammatory pathway expression, anti-angiogenesis effects, and induced differentiation have been observed [5-12]. Anthocyanins administered in vivo have reduced cancer development in animals treated with carcinogens, and in animals with the common hereditary development of colon, lung, skin and esophageal cancers [13-15]. Anthocyanins, 
which degrade rapidly, are the least stable class of flavonoids. The stability of anthocyanins is affected by $\mathrm{pH}$, light exposure, oxidation, enzymatic action, and the presence of metal ions [16]. Under acidic conditions $(\mathrm{pH}<3)$, anthocyanins exist in their most stable form, red flavylium cations. When the $\mathrm{pH}$ is between four and five, anthocyanins undergo hydroxylation and form a colorless pseudo base. At a higher $\mathrm{pH}(\mathrm{pH}>6)$, anthocyanins exist as a quinoidal base and exhibit a blue color. Under alkaline conditions, anthocyanins can also form chalcones, which exhibit a yellow color, and can degrade to produce phenolic acids [17].

Cyanidin-3-O-glucoside (C3G), which is the predominant anthocyanin in haskap berries [18,19], thermally degrades into protocatechuic acid (PCA) and phloroglucinaldehyde (PGA) [20]. PCA has exhibited anti-inflammatory and anti-oxidative effects and has reduced liver toxicity in vivo [21]. PCA may also possess anti-tumoral properties, inducing apoptosis in human leukemia cells, as well as in human salivary gland carcinoma (HSG1) cells [22]. Conversely, PCA has also been shown to increase proliferation in 12-O-tetradecanoylphorbol-13-acetate (TPA)-induced mouse skin tumors [23]. Currently, limited studies are showing the antiproliferative effects of PGA, with only two studies suggesting anti-proliferative effects against colon cancer cells Caco-2 [24,25]. Recent studies investigating the pharmacokinetics of C3G in humans have identified the presence of both PCA and PGA in the blood serum of individuals who have ingested labeled C3G [26,27]. Therefore, this study aims to characterize C3G degradation, PCA and PGA formation in the haskap extract, and the antiproliferative properties of C3G and its major degradation products against hepatocellular carcinoma HepG2 and breast adenocarcinoma MDA-MB-231 cells.

\section{Materials and Methods}

\subsection{Plant Material}

Haskap berries of the Tundra cultivar (TN) were obtained from LaHave Natural Farm, Blockhouse, Nova Scotia, Canada and stored at $-20^{\circ} \mathrm{C}$.

\subsection{Chemicals and Reagents}

High performance liquid chromatography (HPLC) grade methanol, ethyl acetate, $88 \%$ formic acid, acetone, phosphate buffered saline (PBS), dimethyl sulfoxide (DMSO), Eagle Minimum Essential Growth Medium (EMEM), Dulbecco's Modified Eagle's Medium (DMEM), penicillin-streptomycin, fetal bovine serum (FBS), PCA, PGA, doxorubicin (DOX), and all other chemical reagents were purchased from Sigma-Aldrich (Oakville, ON, Canada). C3G was purchased from Extrasynthese (Genay Cedrix, France). Trisodium citrate and anhydrous dibasic sodium phosphate were purchased from Fisher Scientific (Ottawa, ON, Canada). Sorafenib was purchased from Cayman Chemicals (Cedarlane, Burlington, ON, Canada). 5-[3-(Carboxymethoxy) phenyl]-3-(4,5-dimethyl2-thiazolyl)-2-(4-sulfophenyl)-2H-tetrazolium inner salt (MTS) was purchased from Promega (Madison, WI, USA).

\subsection{Preparation of Extracts}

\subsubsection{Preparation of Crude Extract}

The crude extract (CE) was prepared using frozen haskap berries (500 g) extracted in semi-dark conditions. Berries were ground in a blender (Model HBB909, Hamilton Beach Brands Inc., Glen Allen, VA, USA) in a solution of 70:28:2 acetone:deionized water $\left(\mathrm{DI} \mathrm{H}_{2} \mathrm{O}\right)$ :formic acid. For every $1 \mathrm{~g}$ of frozen berries, $4 \mathrm{~mL}$ of solvent was used. The blended berries and solvent were filtered through six layers of cheese cloth, then vacuum filtered through Whatman \# 8 filter paper (Fisher Scientific, Ottawa, $\mathrm{ON}$, Canada). Samples were subjected to rotary evaporation to remove the solvent, then frozen at $-80{ }^{\circ} \mathrm{C}$ and freeze-dried. Crude extracts were then stored at $-80^{\circ} \mathrm{C}$. 


\subsubsection{Preparation of C3G-Rich Fraction}

C3G-rich fraction (PE) was prepared in the same manner as crude extracts with additional steps, as described in a previous method [28]. Following rotary evaporation to remove acetone, the resultant liquid was added to equal volumes of ethyl acetate in a separatory funnel under dark conditions and was allowed to separate for $12 \mathrm{~h}$ before the aqueous phase was collected. Trace amounts of ethyl acetate were removed from the aqueous phase via rotary evaporation. A column $(3.8 \times 45 \mathrm{~cm}$, Sati International Scientific Inc., Dorval, QC, Canada) was packed with $600 \mathrm{~g}$ adsorbent (Sorbent SP207-05 Sepabeads Resin Brominated Styrenic Adsorbent: particle size $250 \mu \mathrm{m}$, surface area $630 \mathrm{~m}^{3} / \mathrm{g}$, Sorbent Technologies, Atlanta, GA, USA) and conditioned with methanol followed by $\mathrm{DI}_{2} \mathrm{O}$ acidified to $\mathrm{pH} 2.5$ with hydrochloric acid $(\mathrm{HCl})$. The crude extract was applied to the column and washed with $1 \mathrm{~L} \mathrm{DI} \mathrm{H}_{2} \mathrm{O}$ acidified to $\mathrm{pH} 2.5$ with $\mathrm{HCl}$. C3G-rich fraction was eluted with about $500 \mathrm{~mL}$ of methanol. Methanol was removed using rotary evaporation and then freeze-dried to prepare dried PE, which was stored at $-80^{\circ} \mathrm{C}$.

\subsection{Degradation Kinetics}

\subsubsection{Sample Preparation}

PE was prepared at a concentration of $40 \mathrm{mg} / \mathrm{mL}$ in a citrate-phosphate buffer $(0.2 \mathrm{M}$ tri-sodium citrate, $0.3 \mathrm{M}$ dibasic sodium phosphate). Portions of this solution were acidified to $\mathrm{pH} 2.5,4$, and 7 with citric acid and stored in 2-mL aliquots in 2-mL sealed amber glass vials. Samples were incubated in triplicate, in a water bath at either $70^{\circ} \mathrm{C}$ or $90^{\circ} \mathrm{C}$, for periods of $0,0.5,1,2,4$, or $8 \mathrm{~h}$. After incubation, samples were immersed in an ice bath to limit further degradation. Samples were then stored at $-80^{\circ} \mathrm{C}$ until analysis. Pure PGA solutions $(50 \mu \mathrm{g} / \mathrm{mL}, 2 \mathrm{~mL})$ were incubated in a $90{ }^{\circ} \mathrm{C}$ water bath for $0,0.5,1,2,4$, and $8 \mathrm{~h}$ periods in 2-mL sealed amber glass vials at $\mathrm{pH}$ of 2.5, 4, and 7. Each of the heated solutions was diluted with $2 \mathrm{~mL} \mathrm{MeOH}$ and filtered before HPLC analysis.

\subsubsection{Quantification of Total Monomeric Anthocyanins, C3G, PCA, and PGA}

Total monomeric anthocyanin concentration (TAC) was determined using a spectrophotometric $\mathrm{pH}$ differential method [29]. The TAC is expressed as milligrams (mg) C3G equivalent with a molar extinction coefficient 26,900 and a molecular weight of $449.2 \mathrm{~g} / \mathrm{mol}$. C3G, PGA, and PCA were quantified as described before by [28] using ultra HPLC electrospray ionization tandem mass spectrometry (UPLC-ESI-MS/MS) on a Waters H-class UPLC separations module (Waters, Milford, MA, USA) coupled with a Micromass Quattro micro API MS/MS system and MassLynx V4.0 control software (Micromass, Cary, NC, USA). The column used was an Aquity BEH C18 $(100 \mathrm{~mm} \times 2.1 \mathrm{~mm} \times 1.7 \mu \mathrm{m})$ (Waters, Milford, MA, USA). PCA and PGA were analyzed using single ion monitoring mode (SIM) with electrospray ionization in negative mode (ESI-) with a capillary voltage of $3000 \mathrm{~V}$, a nebulizer gas temperature $\left(\mathrm{N}_{2}\right)$ of $375^{\circ} \mathrm{C}$, and a flow rate of $0.35 \mathrm{~mL} / \mathrm{min}$. C3G was analyzed using electrospray ionization in positive ion mode (ESI+), with a capillary voltage of $3500 \mathrm{~V}$, a nebulizer gas temperature $\left(\mathrm{N}_{2}\right)$ of $375{ }^{\circ} \mathrm{C}$, and a flow rate of $0.35 \mathrm{~mL} / \mathrm{min}$. Samples were diluted 1:1 with methanol, then filtered through $0.22 \mu \mathrm{m}$ nylon filters into amber glass UPLC vials.

\subsubsection{Statistical Analysis}

Repeated measures analysis $(p \leq 0.05)$ was performed using the statistical analysis system software (SAS Institute, Cary, NC, USA). The data for C3G incubated at $90{ }^{\circ} \mathrm{C}$ was normalized using a $\log _{10}$ transformation. 


\subsection{Antiproliferative Activity}

\subsubsection{Preparation of Extracts}

PE was prepared for cell-based assays by dissolving freeze-dried PE to a concentration of $60 \mathrm{mg} / \mathrm{mL}$ in deionized water $\left(\mathrm{DI} \mathrm{H}_{2} \mathrm{O}\right)$. Degraded extracts were prepared by subjecting aliquots of this PE solution to thermal degradation at $90^{\circ} \mathrm{C}$ in a shaking water bath for $2 \mathrm{~h}$ (HPE2) or $8 \mathrm{~h}$ (HPE8). The crude extract (CE) was prepared by dissolving freeze-dried CE to a concentration of $60 \mathrm{mg} / \mathrm{mL}$ in $\mathrm{DI} \mathrm{H}_{2} \mathrm{O}$.

\subsubsection{Cell Culture}

Breast adenocarcinoma (MDA-MB-231; American Type Culture Collection (ATCC) \# HTB 26) cells were obtained from the American Type Culture Collection (ATCC, Manassas, VA, USA) and cultured at $37{ }^{\circ} \mathrm{C}$ with $5 \% \mathrm{CO}_{2}$, in DMEM with $2 \mathrm{mM}$ L-glutamine, $10 \%$ heat-inactivated FBS, 1\% 4-(2-hydroxyethyl)-1-piperazineethanesulfonic acid (HEPES), and 1\% penicillin-streptomycin. Hepatocellular carcinoma (HepG2; ATCC \# 8065) cells were also obtained from the ATCC and cultured in EMEM with $2 \mathrm{mM}$ L-glutamine, $10 \% \mathrm{FBS}$, and $1 \%$ penicillin-streptomycin at $37{ }^{\circ} \mathrm{C}$ with $5 \% \mathrm{CO}_{2}$.

\subsubsection{Cell Viability MTS Assay}

A CellTiter $96^{\circledR}$ AQueous One Solution Cell Proliferation Assay (Promega, Madison, WI, USA) was used to determine cell viability. Cells were seeded in 96-well plates at a density of $5 \times 10^{3}$ cells per well and incubated for $24 \mathrm{~h}$ to promote cell adhesion. Cells were treated with PE, HPE2, HPE8, or CE. For HepG2 cells, treatments were added at concentrations of 75, 150, and $300 \mu \mathrm{g} / \mathrm{mL}$ with a positive control of sorafenib in DMSO with a final concentration of $10 \mu \mathrm{g} / \mathrm{mL}$ and negative controls consisting of either EMEM with: $0.5 \%$ DI $\mathrm{H}_{2} \mathrm{O}$ for PE, HPE2, HPE8, or CE treatments, or $0.5 \%$ DMSO for PCA or PGA treatments. For MDA-MB-231 cells, treatments were added at concentrations of 50, 100 , and $200 \mu \mathrm{g} / \mathrm{mL}$ with a positive control of doxorubicin in DMSO at a final concentration of $50 \mu \mathrm{M}$, and negative controls of DMEM with either $0.5 \%$ DI $\mathrm{H}_{2} \mathrm{O}$ (PE, HPE2, HPE8, or CE) or $0.5 \%$ DMSO (PCA, PGA). After either a 24 or $48 \mathrm{~h}$ incubation, $20 \mu \mathrm{L}$ of MTS was added to each well. Plates were incubated for three hours at $37^{\circ} \mathrm{C}$ in a $5 \% \mathrm{CO}_{2}$ atmosphere before absorbance was measured at $490 \mathrm{~nm}$ using a FLUOstar Optima microplate reader (BMG Labtech, Ortenberg, Germany). Cell viability calculated with treated cells being expressed as a percent of cells treated with vehicle only.

\subsubsection{Acid Phosphatase Assay}

Acid phosphatase buffer was prepared with $0.1 \mathrm{M}$ sodium acetate $(\mathrm{NaAc}), 0.1 \% v / v$ Triton $\mathrm{X}-100$, and $4 \mathrm{mg} / \mathrm{mL}$ phosphatase substrate (Sigma-Aldrich, Oakville, ON, Canada), adjusted to a pH of 5.5 with $\mathrm{HCl}$, and stored at $4{ }^{\circ} \mathrm{C}$. HepG2 cells were treated with PE, PCA, and PGA at concentrations of 75,150 , and $300 \mu \mathrm{g} / \mathrm{mL}$ with a positive control of sorafenib in DMSO with a final concentration of $10 \mu \mathrm{g} / \mathrm{mL}$, and negative controls consisting of EMEM with either: $0.5 \% \mathrm{DI}_{2} \mathrm{O}$ for PE treatments, or $0.5 \%$ DMSO for PCA or PGA treatments. After incubation for a period of 48 $\mathrm{h}$, plates were centrifuged at $2000 \mathrm{rpm}$ for $10 \mathrm{~min}$ before the supernatant was removed and $100 \mu \mathrm{L}$ of PBS added to each well. Plates were again centrifuged before PBS was removed and $100 \mu \mathrm{L}$ of assay buffer was added to each well. Plates were then incubated for two hours at $37^{\circ} \mathrm{C}$ in a $5 \% \mathrm{CO}_{2}$ atmosphere. After incubation, $10 \mu \mathrm{L}$ of $1 \mathrm{~N}$ sodium hydroxide was added to each well, and absorbance was measured at $405 \mathrm{~nm}$ using a FLUOstar Optima microplate reader (BMG Labtech, Ortenberg, Germany). Cell viability was calculated as described in Section 2.5.3.

\subsubsection{Adenosine Triphosphate (ATP) Assay}

The CellTiter-Glo ${ }^{\circledR}$ Luminescent Cell Viability Assay (Promega, Madison, WI, USA) was used to determine cell viability and ATP levels. HepG2 cells were treated under the same conditions as 
those in the acid phosphatase assay. The CellTiter-Glo ${ }^{\circledR}$ reagent was prepared as directed by the manufacturer from CellTiter-Glo ${ }^{\circledR}$ substrate and the CellTiter-Glo ${ }^{\circledR}$ buffer, and $100 \mu \mathrm{L}$ of reagent was added to each well. Plates were shaken for $2 \mathrm{~min}$ at $60 \mathrm{rpm}$ using a VWR orbital shaker (Troemner LLC, Mini Shaker, Thorofare, NJ, USA) to induce cell lysis followed by a 10-min room-temperature incubation. Luminescence was measured using a FLUOstar Optima microplate reader (BMG Labtech, Ortenberg, Germany). Cell viability was calculated as described in Section 2.5.3.

\subsubsection{Statistical Analysis}

All experiments were designed using completely randomized design. Assays were performed in triplicate $(n=3)$, and all results were expressed as the mean \pm standard deviation (SD). Analyses were compared using one-way analysis of variance (ANOVA) and Tukey's test $(p \leq 0.05)$. Statistical analyses were carried out using the Minitab v.17 software (Minitab, State College, PA, USA) package.

\section{Results}

\subsection{C3G Degradation}

Monomeric anthocyanins' degradation was more pronounced in extracts incubated at $90{ }^{\circ} \mathrm{C}$ than at $70{ }^{\circ} \mathrm{C}$ (Figure 1A,E). Also, extracts incubated at the $\mathrm{pH}$ of 7.0 exhibited significantly greater anthocyanin degradation than extracts incubated in acidic $\mathrm{pH}$ conditions. As demonstrated in Figure $1 \mathrm{~B}, \mathrm{~F}$, at incubation temperatures of $70{ }^{\circ} \mathrm{C}$ and $90{ }^{\circ} \mathrm{C}$, the breakdown of $\mathrm{C} 3 \mathrm{G}$ in haskap PE was significantly affected $(p \leq 0.05)$ by both incubation time and $\mathrm{pH}$.
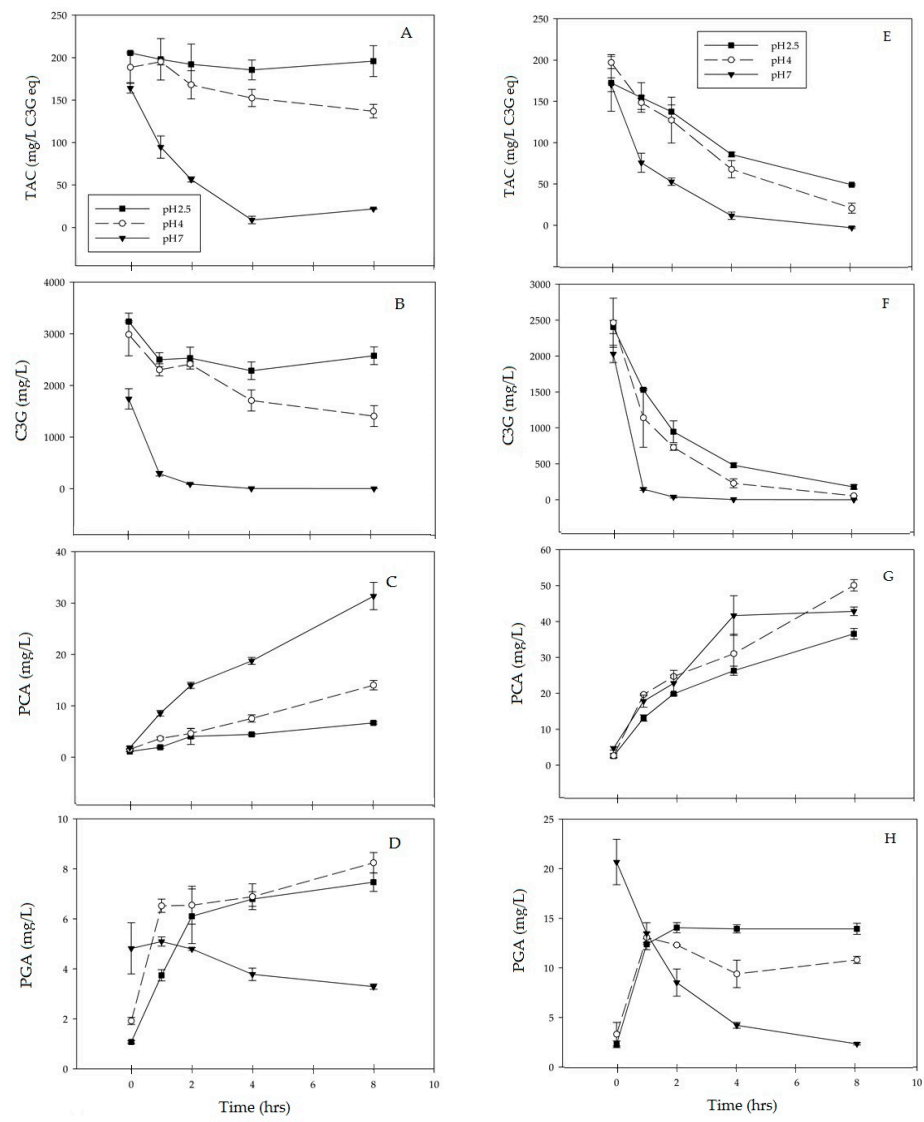

Figure 1. Total monomeric anthocyanin (TAC), cyanidin-3-O-glucoside (C3G), protocatechuic acid (PCA) and phloroglucinaldehyde (PGA) content at $70{ }^{\circ} \mathrm{C}(\mathbf{A}-\mathbf{D})$ and $90^{\circ} \mathrm{C}(\mathrm{E}-\mathbf{H})$. TAC was measured using $\mathrm{pH}$ differential spectrophotometric assay and quantification of $\mathrm{C} 3 \mathrm{G}, \mathrm{PCA}$, and PGA by ultra HPLC electrospray ionization tandem mass spectrometry (UPLC-ESI-MS/MS). 
As the $\mathrm{pH}$ increased, $\mathrm{C} 3 \mathrm{G}$ degraded more readily, with extracts incubated at $90{ }^{\circ} \mathrm{C}$ degrading more quickly than those incubated at $70{ }^{\circ} \mathrm{C}$. Extracts incubated for $8 \mathrm{~h}$ at $\mathrm{pH} 2.5, \mathrm{lost} 21 \%$ of the initial C3G content at $70{ }^{\circ} \mathrm{C}$, and lost $95 \%$ of the initial C3G content at $90{ }^{\circ} \mathrm{C}$. Extracts at $\mathrm{pH} 4.0$ followed a similar trend losing $53 \%$ of the $\mathrm{C} 3 \mathrm{G}$ content at $70{ }^{\circ} \mathrm{C}$ versus a $98 \%$ loss at $90{ }^{\circ} \mathrm{C}$. At pH 7.0, C $3 \mathrm{G}$ was almost completely lost at both $70{ }^{\circ} \mathrm{C}$ and $90^{\circ} \mathrm{C}$. C3G is the least stable at $\mathrm{pH} 7$ when compared to $\mathrm{pH}$ 2.5 and $\mathrm{pH} 4.0$ (Figure 1B,F).

\subsection{Formation of $P C A$}

The accumulation of PCA, one of C3G's major breakdown products, was quantified in the thermally degraded purified extracts. PCA concentration increased as C3G degraded under all tested conditions. Time and $\mathrm{pH}$ both significantly $(p \leq 0.05)$ affected the accumulation of PCA as C3G degraded. The highest concentration of accumulated PCA, $50.0 \mathrm{mg} / \mathrm{L}$, was observed over an 8-h incubation at $\mathrm{pH} 4$ and $90^{\circ} \mathrm{C}$. As with C3G degradation, at $70{ }^{\circ} \mathrm{C}$ the largest differences in PCA concentrations were found when comparing $\mathrm{pH} 7.0$ to an acidic $\mathrm{pH}$ of 2.5 or 4.0 . At $90^{\circ} \mathrm{C}$ variations were less dramatic, suggesting that the presence of PCA in C3G-rich extracts is an indicator of C3G degradation (Figure 1C,G).

\subsection{Formation of $P G A$}

PGA concentration (Figure 1D,H) showed less of an association to C3G degradation than PCA concentration. At $70{ }^{\circ} \mathrm{C}$ and $90^{\circ} \mathrm{C}$, and pHs of 2.5 and 4.0, extracts showed an increase in PGA concentration, with most of the accumulation occurring during the first $2 \mathrm{~h}$ of the 8 -h incubation. Depending on incubation conditions, after the initial $2 \mathrm{~h}$, PGA accumulation decelerated, stabilized, or for $\mathrm{pH} 7.0$ at both $70^{\circ} \mathrm{C}$ and $90^{\circ} \mathrm{C}$ PGA concentration decreased.

To understand whether the PGA can be further degraded at $\mathrm{pH} 7$ after $2 \mathrm{~h}$, the second experiment was performed using pure PGA (Figure 2). PGA heated at $\mathrm{pH}$ of 2.5 and 4 showed minimal degradation over the $8 \mathrm{~h}$ period. However, at $\mathrm{pH} 7$, the PGA experienced rapid degradation and exhibited over $90 \%$ loss after $8 \mathrm{~h}$ of heating. This is in agreement with the previous experiment, which found that PGA accumulated from $\mathrm{C} 3 \mathrm{G}$ degradation had decreased concentrations at $\mathrm{pH}$ 7. A visible color change could be seen with PGA solutions mixed with the $\mathrm{pH} 7$ buffer; PGA solutions at $\mathrm{pH} 2.5$ and 4 remained colorless, while $\mathrm{pH} 7$ solutions became increasingly yellow with longer heating times.

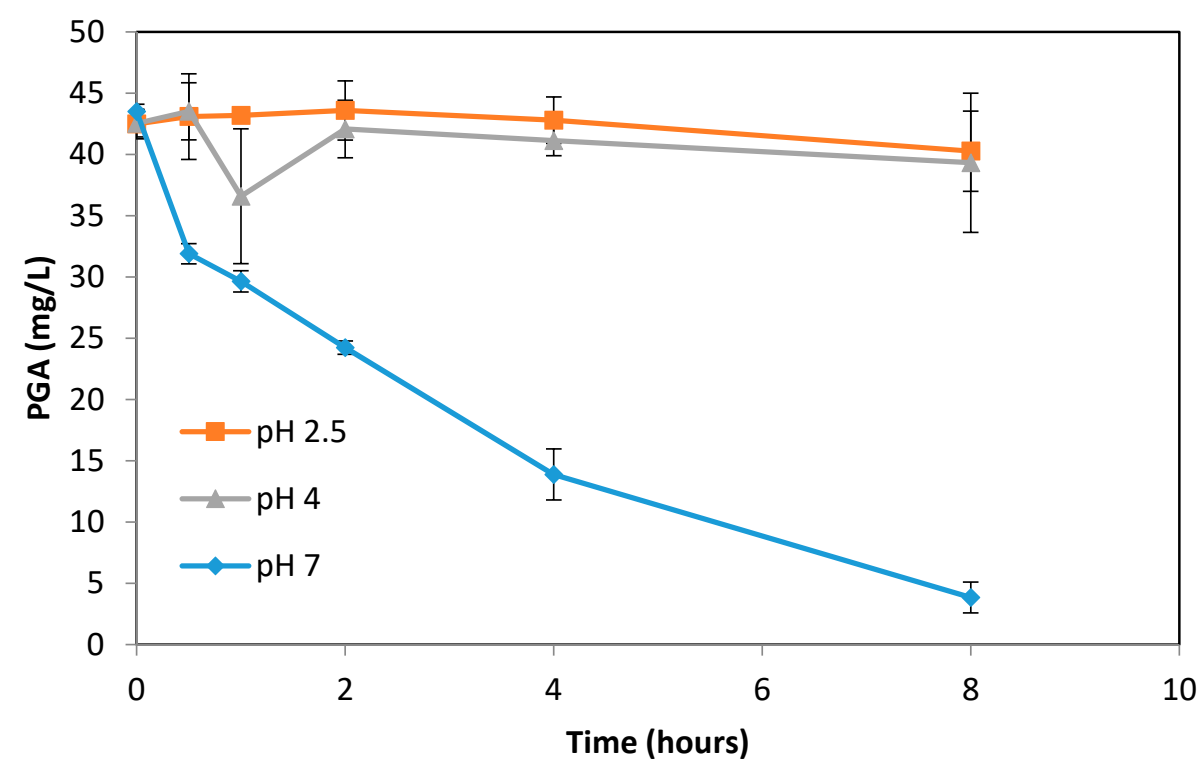

Figure 2. Phloroglucinaldehyde (PGA) concentration at $90^{\circ} \mathrm{C}$ at $\mathrm{pH} 2.5,4$, and 7 , respectively. 


\subsection{Breast Adenocarcinoma MDA-MB-231 Viability}

The viability of treated MDA-MB-231 cells was assessed using an MTS assay. PE, HPE2, HPE8, CE, PCA, and PGA were used to treat the cells. The concentrations of C3G, PCA, and PGA in each extract are displayed in Table 1. Cellular viability was measured by comparing cells treated with extracts and commercially purchased PCA and PGA, at concentrations of 50,100, and $200 \mu \mathrm{g} / \mathrm{mL}$, to negative and positive controls. The negative control consisted of DMEM growth medium with $0.5 \% \mathrm{DMSO}$, and the positive control was $0.5 \% \mathrm{DMSO}$ with the chemotherapy drug doxorubicin at a concentration of $50 \mu \mathrm{M}$.

Table 1. The composition of the C3G-rich extracts and thermally-challenged extracts $(500 \mu \mathrm{g} / \mathrm{mL})$ used for the cell viability analyses.

\begin{tabular}{cccc}
\hline Treatment & C3G $(\mu \mathrm{g} / \mathrm{mL})$ & PCA $(\mu \mathrm{g} / \mathrm{mL})$ & PGA $(\mu \mathrm{g} / \mathrm{mL})$ \\
\hline PE & $59.92 \pm 1.6$ & $0.28 \pm 0.001$ & $0.023 \pm 0.0002$ \\
HPE2 & $34.23 \pm 3.3$ & $0.77 \pm 0.04$ & $0.29 \pm 0.01$ \\
HPE8 & $5.76 \pm 0.5$ & $2.02 \pm 0.2$ & $0.467 \pm 0.01$ \\
CE & $11.35 \pm 0.1$ & N $/ \mathrm{A}$ & N $/ A$
\end{tabular}

C3G, Cyanidin-3-O-glucoside; PCA, protocatechuic acid; PGA, phloroglucinaldehyde; PE, C3G-rich fraction; HPE2, the PE subjected to $90^{\circ} \mathrm{C}$ for $2 \mathrm{~h}$; HPE8, the PE subjected to $90^{\circ} \mathrm{C}$ for $8 \mathrm{~h}$; CE, crude extract.

None of the haskap-derived treatments affected cellular viability except PGA (Table 2). At concentrations of $100 \mu \mathrm{g} / \mathrm{mL}$ and above, PGA significantly reduced MDA-MB-231 viability over periods of 24 and $48 \mathrm{~h}$. In both cases, a cell viability of 35\% was observed; with a strong dose-dependent trend but no clear time-dependence.

\subsection{Hepatocellular Carcinoma HepG2 Cell Viability}

The viability of HepG2 cells, after exposure to haskap berry extracts containing C3G and its metabolites, was assessed using an MTS assay, an acid phosphatase assay, and an ATP assay. Cellular viability was compared to a negative control consisting of EMEM growth medium with $0.5 \%$ DMSO, and a positive control containing $10 \mu \mathrm{g} / \mathrm{mL}$ of the chemotherapy drug sorafenib. Cells were treated with PE, HPE2, HPE8, CE, PCA, and PGA at concentrations of 75, 150, and $300 \mu \mathrm{g} / \mathrm{mL}$.

MTS-based viability determination (Table 2) showed a dose- and time-dependent reduction in cell viability for PE and PGA. After a 24 -h incubation, cell viability was $52 \%$ with a PGA concentration of $75 \mu \mathrm{g} / \mathrm{mL}$, and only $20.2 \%$ with a concentration of $300 \mu \mathrm{g} / \mathrm{mL}$, when compared to the negative control. For PE at $300 \mu \mathrm{g} / \mathrm{mL}$ after a $24-\mathrm{h}$ incubation, cell viability was $64 \%$ compared to the negative control. PCA treatments showed no effect on HepG2 viability as determined via MTS assay. Treatments showing dose-dependent inhibition (PE \& PGA), along with PCA due to conflicting reports of its anti-tumorigenic activity, were selected for further testing over 48-h incubations.

Cell viability, as determined in an acid phosphatase assay, showed that PE (Figure 3A) induced a strong dose-dependent reduction in cellular viability. This reduction ranged from $84.5 \%$ at a dosage of $75 \mu \mathrm{g} / \mathrm{mL}$, to $21.2 \%$ at $300 \mu \mathrm{g} / \mathrm{mL}$, as seen in Figure 3A. PGA also induced a significant reduction in cell viability, with all three treatments exhibiting similar activity to the positive control. PCA showed no significant dose-dependent reduction in cellular viability. 
Table 2. Cell viability measured using the MTS assay.

\begin{tabular}{|c|c|c|c|}
\hline Treatment & $\begin{array}{l}\text { Concentration } \\
(\mu \mathrm{g} / \mathrm{mL})\end{array}$ & $\begin{array}{c}24 \mathrm{~h} \\
(\% \text { Viability } \pm \text { SD) }\end{array}$ & $\begin{array}{c}48 \mathrm{~h} \\
(\% \text { Viability } \pm \text { SD) }\end{array}$ \\
\hline \multirow{4}{*}{ PE } & & MDA-MB-231 & \\
\hline & 50 & $97.43 \pm 2.04^{\mathrm{ab}}$ & $103.10 \pm 10.17^{a}$ \\
\hline & 100 & $107.02 \pm 6.71^{a b}$ & $105.15 \pm 5.29^{a}$ \\
\hline & 200 & $109.86 \pm 1.50 \mathrm{ab}$ & $106.52 \pm 6.50^{\mathrm{a}}$ \\
\hline \multirow[t]{3}{*}{ HPE2 } & 50 & $100.22 \pm 2.14^{\mathrm{cd}}$ & $98.34 \pm 0.91^{\mathrm{a}}$ \\
\hline & 100 & $104.96 \pm 1.42^{\mathrm{ab}}$ & $106.43 \pm 4.20^{\mathrm{a}}$ \\
\hline & 200 & $108.38 \pm 4.16^{\mathrm{ab}}$ & $94.13 \pm 8.44^{a}$ \\
\hline \multirow[t]{3}{*}{ HPE8 } & 50 & $103.82 \pm 2.48^{\mathrm{ab}}$ & $107.68 \pm 6.24^{\mathrm{a}}$ \\
\hline & 100 & $104.19 \pm 4.13^{a b}$ & $104.78 \pm 4.45^{\mathrm{a}}$ \\
\hline & 200 & $100.55 \pm 3.11^{a b}$ & $85.10 \pm 11.13^{a}$ \\
\hline \multirow[t]{3}{*}{$\mathrm{CE}$} & 50 & $103.31 \pm 4.98^{a b}$ & $105.37 \pm 3.46^{\mathrm{a}}$ \\
\hline & 100 & $99.33 \pm 3.24^{\mathrm{ab}}$ & $98.99 \pm 12.10^{a}$ \\
\hline & 200 & $98.73 \pm 2.18^{a b}$ & $99.16 \pm 3.86^{\mathrm{a}}$ \\
\hline \multirow{3}{*}{ PCA } & 50 & $101.18 \pm 11.40^{a b}$ & $94.43 \pm 6.65^{\mathrm{a}}$ \\
\hline & 100 & $101.08 \pm 8.12^{\mathrm{ab}}$ & $81.96 \pm 13.33^{a}$ \\
\hline & 200 & $107.89 \pm 10.21^{\mathrm{ab}}$ & $86.96 \pm 29.52^{a}$ \\
\hline \multirow[t]{3}{*}{ PGA } & 50 & $78.22 \pm 2.37 \mathrm{bc}$ & $80.35 \pm 5.54^{\mathrm{a}}$ \\
\hline & 100 & $35.30 \pm 26.66^{d}$ & $36.25 \pm 5.11 \mathrm{bc}$ \\
\hline & 200 & $7.09 \pm 8.93^{\mathrm{e}}$ & $17.71 \pm 13.55^{c}$ \\
\hline \multirow[t]{2}{*}{ Dox } & 27.2 & $53.30 \pm 13.56^{\mathrm{cd}}$ & $7.89 \pm 7.29^{c}$ \\
\hline & & HepG2 & \\
\hline \multirow[t]{3}{*}{ PE } & 75 & $89.26 \pm 11.01 \mathrm{bc}$ & $72.9 \pm 3.07 \mathrm{~cd}$ \\
\hline & 150 & $88.39 \pm 2.43^{b c}$ & $70.97 \pm 7.32 \mathrm{~d}$ \\
\hline & 300 & $64.32 \pm 14.33^{\mathrm{cd}}$ & $35.57 \pm 11.55 \mathrm{e}$ \\
\hline \multirow[t]{3}{*}{ HPE2 } & 75 & $105.92 \pm 7.78^{a b}$ & $92.09 \pm 4.61^{\mathrm{abc}}$ \\
\hline & 150 & $104.28 \pm 9.19 \mathrm{ab}$ & $91.26 \pm 5.18^{\mathrm{abcd}}$ \\
\hline & 300 & $97.34 \pm 8.48^{\mathrm{ab}}$ & $81.58 \pm 6.69 \mathrm{bcd}$ \\
\hline \multirow[t]{3}{*}{ HPE8 } & 75 & $105.64 \pm 8.35^{a b}$ & $90.15 \pm 7.96^{\mathrm{abcd}}$ \\
\hline & 150 & $102.85 \pm 5.86^{\mathrm{ab}}$ & $81.65 \pm 10.15^{b c d}$ \\
\hline & 300 & $103.35 \pm 5.08^{a b}$ & $80.07 \pm 6.22 \mathrm{bcd}$ \\
\hline \multirow[t]{3}{*}{$\mathrm{CE}$} & 75 & $102.92 \pm 3.59 \mathrm{ab}$ & $95.2 \pm 5.03^{a b}$ \\
\hline & 150 & $102.59 \pm 7.62^{a b}$ & $94.67 \pm 3.6^{a b}$ \\
\hline & 300 & $104.76 \pm 4.90^{\mathrm{ab}}$ & $93.35 \pm 3.29 \mathrm{abc}$ \\
\hline \multirow[t]{3}{*}{ PCA } & 75 & $84.98 \pm 4.04 \mathrm{bc}$ & $90.943 \pm 1.6^{\mathrm{abcd}}$ \\
\hline & 150 & $92.41 \pm 8.27 \mathrm{ab}$ & $89.99 \pm 7.21 \mathrm{abcd}$ \\
\hline & 300 & $114.06 \pm 7.53^{a b}$ & $108.66 \pm 7.77^{a}$ \\
\hline \multirow[t]{3}{*}{ PGA } & 75 & $52.85 \pm 3.82$ de & $25.71 \pm 7.07$ ef \\
\hline & 150 & $18.34 \pm 10.46^{\mathrm{f}}$ & $15.16 \pm 7.36$ efg \\
\hline & 300 & $20.23 \pm 8.25^{f}$ & $1.80 \pm 1.70 \mathrm{~g}$ \\
\hline Sorafenib & 10 & $39.38 \pm 5.48$ ef & $11.40 \pm 9.22 \mathrm{fg}$ \\
\hline
\end{tabular}

Results represent the mean $\pm \mathrm{SD}$, Letters $(\mathrm{a}-\mathrm{g})$ indicate significantly different means $(p \leq 0.05)$ within temperature treatments. MTS: 5-[3-(Carboxymethoxy) phenyl]-3-(4,5-dimethyl-2-thiazolyl)-2-(4-sulfophenyl)-2H-tetrazolium inner salt. 

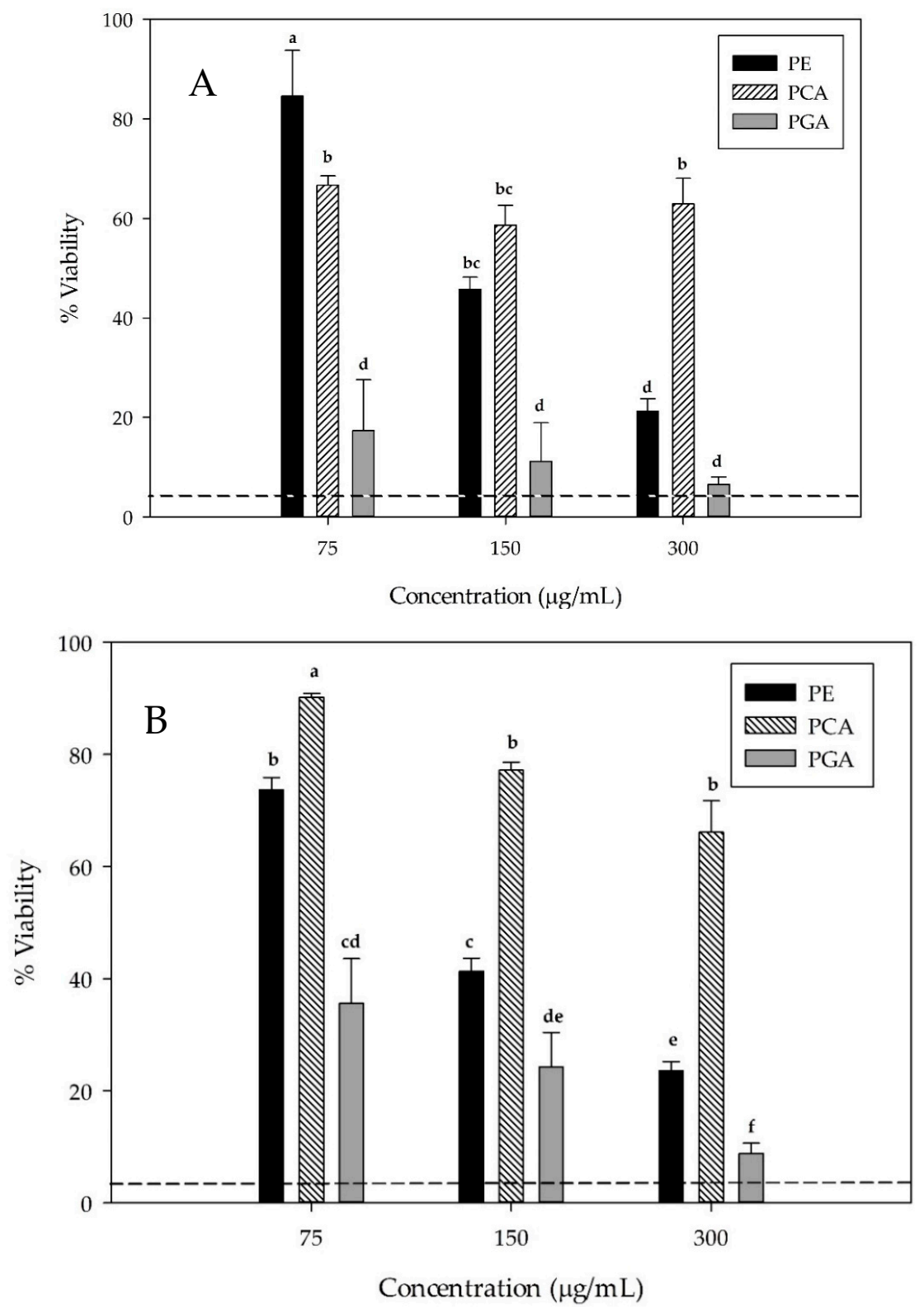

Figure 3. Cellular viability (\% relative to the control) as determined by an acid phosphatase assay (A) and ATP content (B) of HepG2 cells incubated with C3G-rich fraction (PE), PCA, and PGA for $48 \mathrm{~h}$. Dashed line represents positive control sorafenib at a concentration of $10 \mu \mathrm{g} / \mathrm{mL}$. Letters (a-f) on the bars indicate significantly different means $(p \leq 0.05)$. PE, C3G-rich fraction; PCA, protocatechuic acid; PGA, phloroglucinaldehyde.

It was determined via an ATP assay that PE-induced a dose-dependent reduction in ATP activity after an incubation of $48 \mathrm{~h}$ (Figure 3B). PE added at a concentration of $75 \mu \mathrm{g} / \mathrm{mL}$ did not generate a value that was significantly different from the vehicle control $(p \leq 0.05)$; however, PE added at a concentration of $300 \mu \mathrm{g} / \mathrm{mL}$ induced an ATP reduction to $23.5 \%$. PGA induced a strong reduction in detectable ATP, ranging from $35.6 \%$ of luminescence at a concentration of $75 \mu \mathrm{g} / \mathrm{mL}$, to $8.8 \%$ at a concentration of $300 \mu \mathrm{g} / \mathrm{mL}$ (Figure3B). PCA induced a slight dose-dependent reduction in luminescence with $150 \mu \mathrm{g} / \mathrm{mL}$ and $300 \mu \mathrm{g} / \mathrm{mL}$ being significantly different than the negative control, but not significantly different from each other. 


\section{Discussion}

Numerous studies and reviews have investigated and confirmed that anthocyanins undergo first-order kinetic degradation [30-34]. At a neutral $\mathrm{pH}$, anthocyanins are liable to undergo spontaneous degradation, making the treatment temperature less significant for samples at neutral $\mathrm{pH}[16,30,35]$. As demonstrated in Figures 1 and 2, for samples degraded at both $70{ }^{\circ} \mathrm{C}$ and $90{ }^{\circ} \mathrm{C}$ at time 0 , samples at $\mathrm{pH} 7.0$ showed a $\mathrm{C} 3 \mathrm{G}$ reduction of almost $50 \%$ compared to the samples at $\mathrm{pH}$ 2.5. Within a given $\mathrm{pH}, \mathrm{C} 3 \mathrm{G}$ degradation accelerates at higher temperatures. This indicates that for C3G containing products, lower-temperature processing may preserve anthocyanin content compared to higher temperature methods. A study by Khattab et al. [36] monitored anthocyanin degradation in the drying of whole haskap berries at temperatures of 60,100 , and $140{ }^{\circ} \mathrm{C}$. The study found that reductions of $74-76 \%, 79-81 \%$, and $91-95 \%$, respectively, of total anthocyanins were observed at those temperatures. Among the five predominant anthocyanins present in haskap berries, C3G was the least thermally stable [36].

Along with affecting the rate of $\mathrm{C} 3 \mathrm{G}$ degradation, solution $\mathrm{pH}$ may also affect the mechanism of degradation. For $\mathrm{C} 3 \mathrm{G}$ at a $\mathrm{pH}$ of 3.5, it appears that the opening of the pyrylium ring initiates anthocyanin degradation, forming a glycosylated chalcone [37]. For C3G at a $\mathrm{pH}$ of 1 , deglycosylation was proposed as the first step in the degradation pathway [20]. It has been determined that the addition of sugars could help prevent anthocyanin degradation under some storage and treatment conditions [38]. This could be valuable, especially at higher temperatures and both acidic and neutral $\mathrm{pH}$.

As with C3G degradation, the widest variation in PCA concentration was observed between measurements taken at $\mathrm{pH} 2.5$ and 7.0 at $70{ }^{\circ} \mathrm{C}$, with there being slightly less variation at $90{ }^{\circ} \mathrm{C}$. This could indicate an inverse relationship, where PCA concentration could potentially represent the level of C3G degradation (Figure 1). The value of PCA as a bioactive compound is still unknown and PCA does not impart vibrant color, so its value for commercial products is still undetermined. Further investigation into the bioactivity of PCA and its interactions is recommended.

For incubation times longer than $2 \mathrm{~h}$, at both $70{ }^{\circ} \mathrm{C}$ and $90{ }^{\circ} \mathrm{C}$, PGA accumulation slowed or stabilized. For all samples at $\mathrm{pH}$ 7.0, there was a decrease in PGA concentration over time. The decelerating of PGA accumulation could be attributed to PGA degradation. Incubation of pure PGA at $90^{\circ} \mathrm{C}$ at $\mathrm{pH} 7.0$ showed its further degradation (Figure 2). This indicates that, like its parent anthocyanin $\mathrm{C} 3 \mathrm{G}, \mathrm{PGA}$ is unstable at higher $\mathrm{pH}$, and further degrades as the incubation time increases. High $\mathrm{pH}$ values appear to have a prominent effect on the degradation of PGA, which is further accelerated by heating.

Haskap extract did not significantly reduce MDA-MB-231 cell viability. This is likely due to differing anthocyanin profiles between haskap berries and blueberries. Interestingly, PGA significantly reduced the MDA-MB-231 viability, which has not previously been reported. PGA has been shown to be anti-proliferative when incubated with Caco-2 cells in vitro [24,25]. Further studies should be conducted to determine if this reduction in viability is selective, and to elucidate the underlying mechanism. For HepG2 cells exposed to haskap berry extracts, and C3G metabolites, CE reduced cell viability to $64 \%$ when treated at a level of $300 \mu \mathrm{g} / \mathrm{mL}$. Based on the ATP assay, PCA caused a significant reduction in HepG2 viability. PCA has been reported to reduce HepG2 viability [39]. The results of the MTS, ATP, and acid phosphatase assays suggest that PCA and PGA in thermally degraded haskap extracts may not be present in high enough concentrations to induce cytotoxicity in both cancer cell lines. However, both PE and PGA caused dose-dependent inhibition of HepG2.

\section{Conclusions}

Solution $\mathrm{pH}$, incubation time, and temperature affect anthocyanin stability. As these increase, the anthocyanin concentration decreases. C3G is more stable when treated at lower temperatures over longer incubations when compared to shorter incubations at higher temperatures. Incubation at $\mathrm{pH} 7.0$ promotes rapid C3G degradation; therefore, maintaining an acidic $\mathrm{pH}$ during processing is favorable 
for C3G retention. Haskap juice is naturally acidic in nature, and this acidity should be preserved to maintain anthocyanin stability. Haskap berry extract with high levels of C3G produced a time- and dose-dependent inhibition of HepG2 cell proliferation and PGA generated dose-dependent inhibition of MDA-MB-231 cells. This preliminary in vitro study suggests that haskap berry anthocyanins could potentially have cancer chemopreventive properties. It also indicates that the inhibitory effects of haskap berry extracts are mediated, at least in part, by C3G. Further studies are required to determine the anti-cancer potential and mechanism of action of C3G. One of C3G's thermal degradation product and in vivo primary metabolites, PGA, also generated significant anti-proliferative effects on HepG2 cells. Processing of haskap berries and their storage could exacerbate anthocyanin degradation, which could lead to a reduction in putative health benefits for the consumer. Since there is growing interest in the use of fruit-derived C3G as a food additive, natural colorant, dietary antioxidant, and nutraceutical, further research is required to determine the toxicity and biological activity of PGA.

Acknowledgments: This study was supported by grants from the Beatrice Hunter Cancer Research Institute (to Eric Pace), the Natural Sciences and Engineering Research Council (NSERC) of Canada (to Eric Pace and H.P. Vasantha Rupasinghe) and the Chinese Scholarship Council (to Yuanyuan Jiang).

Author Contributions: Eric Pace performed the extractions and impact of temperature studies. Yuanyuan Jiang and Eric Pace conducted the cell culture experiments. Amy Clemens assessed the impact of temperature on PGA. Tennille Crossman assisted with the experiments and writing the manuscript. H.P. Vasantha Rupasinghe, the principal investigator of the project, designed all the experiments. All the co-authors contributed to writing the manuscript and have read and approved the final manuscript.

Conflicts of Interest: The authors have no conflict of interest to declare.

\section{References}

1. Rupasinghe, H.P.V.; Yu, L.J.; Bhullar, K.S.; Bors, B. Haskap (Lonicera caerulea): A new berry crop with high antioxidant capacity. Can. J. Plant Sci. 2012, 92, 1311-1317. [CrossRef]

2. Celli, G.B.; Ghanem, A.; Brooks, M.S.L. Haskap berries (Lonicera caerulea L.)—A critical review of antioxidant capacity and health-related studies for potential value-added products. Food Bioprocess Technol. 2014, 7, 1541-1554. [CrossRef]

3. Khattab, R.; Brooks, M.S.; Ghanem, A. Phenolic analyses of haskap berries (Lonicera caerulea L.): Spectrophotometry versus high performance liquid chromatography. Int. J. Food Prop. 2016, 19, 1708-1725. [CrossRef]

4. Chen, L.; Xin, X.; Yuan, Q.; Su, D.; Liu, W. Phytochemical properties and antioxidant capacities of various colored berries. J. Sci. Food Agric. 2014, 94, 180-188. [CrossRef] [PubMed]

5. Fan, Z.L.; Wang, Z.Y.; Liu, J.R. Cold-field fruit extracts exert different antioxidant and antiproliferative activities in vitro. Food Chem. 2011, 129, 402-407. [CrossRef]

6. Sun, C.; Zheng, Y.; Chen, Q.; Tang, X.; Jiang, M.; Zhang, J.; Li, X.; Chen, K. Purification and anti-tumour activity of cyanidin-3-O-glucoside from Chinese bayberry fruit. Food Chem. 2012, 131, 1287-1294. [CrossRef]

7. Liu, W.; Xu, J.; Wu, S.; Liu, Y.; Yu, X.; Chen, J.; Tang, X.; Wang, Z.; Zhu, X.; Li, X. Selective anti-proliferation of HER2-positive breast cancer cells by anthocyanins identified by high-throughput screening. PLoS ONE 2013, 8, e81586. [CrossRef] [PubMed]

8. Serra, D.; Paixão, J.; Nunes, C.; Dinis, T.C.P.; Almeida, L.M. Cyanidin-3-glucoside suppresses cytokine-induced inflammatory response in human intestinal cells: Comparison with 5-aminosalicylic acid. PLoS ONE 2013, 8, e73001. [CrossRef] [PubMed]

9. Zhao, J.G.; Yan, Q.-Q.; Lu, L.-Z.; Zhang, Y.-Q. In vivo antioxidant, hypoglycemic, and anti-tumor activities of anthocyanin extracts from purple sweet potato. Nutr. Res. Pract. 2013, 7, 359-365. [CrossRef] [PubMed]

10. Aboonabi, A.; Singh, I. Chemopreventive role of anthocyanins in atherosclerosis via activation of Nrf2-ARE as an indicator and modulator of redox. Biomed. Pharmacother. 2015, 72, 30-36. [CrossRef] [PubMed]

11. Rupasinghe, H.P.V.; Boehm, M.M.; Sekhon-Loodu, S.; Parmar, I.; Bors, B.; Jamieson, A.R. Anti-inflammatory activity of haskap cultivars is polyphenols-dependent. Biomolecules 2015, 5, 1079-1098. [CrossRef] [PubMed]

12. Roleira, F.M.F.; Tavares-da-Silva, E.J.; Varela, C.L.; Costa, S.C.; Silva, T.; Garrido, J.; Borges, F. Plant derived and dietary phenolic antioxidants: Anticancer properties. Food Chem. 2015, 183, 235-258. [CrossRef] [PubMed] 
13. Duthie, S.J.; Gardner, P.T.; Morrice, P.C.; Wood, S.G.; Pirie, L.; Bestwick, C.C.; Milne, L.; Duthie, G.G. DNA stability and lipid peroxidation in vitamin E-deficient rats in vivo and colon cells in vitro: Modulation by the dietary anthocyanin, cyanidin-3-glycoside. Eur. J. Nutr. 2005, 44, 195-203. [CrossRef] [PubMed]

14. Fantini, M.; Benvenuto, M.; Masuelli, L.; Frajese, G.; Tresoldi, I.; Modesti, A.; Bei, R. In vitro and in vivo antitumoral effects of combinations of polyphenols, or polyphenols and anticancer drugs: Perspectives on cancer treatment. Int. J. Mol. Sci. 2015, 16, 9236-9282. [CrossRef] [PubMed]

15. Hui, C.; Bin, Y.; Xiaoping, Y.; Long, Y.; Chunye, C.; Mantian, M. Anticancer activities of an anthocyanin-rich extract from black rice against breast cancer cells in vitro and in vivo. Nutr. Cancer 2010, 62, 1128-1136. [CrossRef] [PubMed]

16. Kopjar, M.; Piližota, V. Prevention of thermal degradation of anthocyanins in blackberry juice with addition of different sugars. CyTA-J. Food 2011, 9, 237-242. [CrossRef]

17. Kamiloglu, S.; Capanoglu, E.; Grootaert, C.; Van Camp, J. Anthocyanin absorption and metabolism by human intestinal caco-2 cells-A review. Int. J. Mol. Sci. 2015, 16, 21555-21574. [CrossRef] [PubMed]

18. Chaovanalikit, A.; Thompson, M.M.; Wrolstad, R.E. Characterization and quantification of anthocyanins and polyphenolics in blue honeysuckle (Lonicera caerulea L.). J. Agric. Food Chem. 2004, 52, 848-852. [CrossRef] [PubMed]

19. Kusznierewicz, B.; Piekarska, A.; Mrugalska, B.; Konieczka, P.; Namies, J. Phenolic composition and antioxidant properties of polish blue-berried honeysuckle genotypes by HPLC-DAD-MS, HPLC postcolumn derivatization with ABTS or FC, and TLC with DPPH visualization. J. Agric. Food Chem. 2012, 60, 1755-1763. [CrossRef] [PubMed]

20. Sadilova, E.; Stintzing, F.C.; Carle, R. Thermal degradation of acylated and nonacylated anthocyanins. J. Food Sci. 2006, 71, 504-512. [CrossRef]

21. Liu, C.L.; Wang, J.M.; Chu, C.Y.; Cheng, M.T.; Tseng, T.H. In vivo protective effect of protocatechuic acid on tert-butyl hydroperoxide-induced rat hepatotoxicity. Food Chem. Toxicol. 2002, 40, 635-641. [CrossRef]

22. Babich, H.; Sedletcaia, A.; Kenigsberg, B. In vitro cytotoxicity of protocatechuic acid to cultured human cells from oral tissue: Involvement in oxidative stress. Pharmacol. Toxicol. 2002, 91, 245-253. [CrossRef] [PubMed]

23. Nakamura, Y.; Torikai, K.; Ohto, Y.; Murakami, A.; Tanaka, T.; Ohigashi, H. A simple phenolic antioxidant protocatechuic acid enhances tumor promotion and oxidative stress in female ICR mouse skin: Dose-and timing-dependent enhancement and involvement of bioactivation by tyrosinase. Carcinogenesis 2000, 21, 1899-1907. [CrossRef] [PubMed]

24. Forester, S.C.; Waterhouse, A.L. Gut metabolites of anthocyanins, gallic acid, 3-O-methylgallic proliferation of caco-2 cells. J. Agric. Food Chem. 2010, 58, 5320-5327. [CrossRef] [PubMed]

25. Forester, S.C.; Oteiza, P.; Waterhouse, A.L.; Forester, S.C.; Oteiza, P.; Waterhouse, A.L. The anthocyanin metabolites gallic acid, 3-O-methylgallic acid, and 2,4,6-trihydroxybenzaldehyde decrease human colon cancer cell viability by regulating pro-oncogenic signals. Mol. Carcinog. 2014, 53, 432-439. [CrossRef] [PubMed]

26. De Ferrars, R.M.; Czank, C.; Zhang, Q.; Botting, N.P.; Kroon, P.A.; Cassidy, A.; Kay, C.D. The pharmacokinetics of anthocyanins and their metabolites in humans. Br. J. Pharmacol. 2014, 171, 3268-3282. [CrossRef] [PubMed]

27. Czank, C.; Cassidy, A.; Zhang, Q.; Morrison, D.J.; Preston, T.; Kroon, P.A.; Botting, N.P.; Kay, C.D. Human metabolism and elimination of the anthocyanin, cyanidin-3-glucoside: A 13C-Tracer study. Am. J. Clin. Nutr. 2013, 97, 995-1003. [CrossRef] [PubMed]

28. Bhullar, K.S.; Rupasinghe, H.P.V. Antioxidant and cytoprotective properties of partridgeberry polyphenols. Food Chem. 2015, 168, 595-605. [CrossRef] [PubMed]

29. Lee, J.; Durst, R.W.; Wrolstad, R.E. Determination of total monomeric anthocyanin pigment content of fruit juices, beverages, natural colorants, and wines by the $\mathrm{pH}$ differential method: Collaborative study. J. AOAC Int. 2005, 88, 1269-1278. [PubMed]

30. Liu, L.; Cao, S.Q.; Pan, S.Y. Thermal degradation kinetics of three kinds of representative anthocyanins obtained from blood orange. Agric. Sci. China 2011, 10, 642-649. [CrossRef]

31. Nayak, B.; Liu, R.H.; Tang, J. Effect of processing on phenolic antioxidants of effect of processing on phenolic antioxidants of fruits, vegetables, and grains-A review. Crit. Rev. Food Sci. Nutr. 2015, 55, 887-918. [CrossRef] [PubMed] 
32. Olivas-Aguirre, F.J.; Rodrigo-García, J.; Martínez-Ruiz, N.R.; Cárdenas-Robles, A.I.; Mendoza-Díaz, S.O.; Álvarez-Parrilla, E.; González-Aguilar, G.A.; de la Rosa, L.A.; Ramos-Jiménez, A.; Wall-Medrano, A. Cyanidin-3-O-glucoside: Physical-Chemistry, foodomics and health effects. Molecules 2016, 21, 1264. [CrossRef] [PubMed]

33. Patras, A.; Brunton, N.P.; Donnell, C.O.; Tiwari, B.K. Effect of thermal processing on anthocyanin stability in foods; mechanisms and kinetics of degradation. Trends Food Sci. Technol. 2010, 21, 3-11. [CrossRef]

34. Brenes, C.H.; Del Pozo-Insfran, D.; Talcott, S.T. Stability of copigmented anthocyanins and ascorbic acid in a grape juice model system. J. Agric. Food Chem. 2005, 53, 49-56. [CrossRef] [PubMed]

35. Zorić, Z.; Dragović-Uzelac, V.; Pedisić, S.; Kurtanjek, Ž.; Garofulić, I.E. Kinetics of the degradation of anthocyanins, phenolic acids and flavonols during heat treatments of freeze-dried sour cherry Marasca paste. Food Technol. Biotechnol. 2014, 52, 101-108.

36. Khattab, R.; Ghanem, A.; Brooks, M.S.-L. Stability of haskap berry (Lonicera caerulea L.) anthocyanins at different storage and processing conditions. J. Food Res. 2016, 5, 67. [CrossRef]

37. Sadilova, E.; Carle, R.; Stintzing, F.C. Thermal degradation of anthocyanins and its impact on color and in vitro antioxidant capacity. Mol. Nutr. Food Res. 2007, 51, 1461-1471. [CrossRef] [PubMed]

38. Arslan, D. Effects of degradation preventive agents on storage stability of anthocyanins in sour cherry concentrate. Agron. Res. 2015, 13, 892-899.

39. Yin, M.; Lin, C.-C.; Wu, H.; Tsao, S.; Hsu, C.-K. Apoptotic effects of protocatechuic acid in human breast, lung, liver, cervix, and prostate cancer cells: Potential mechanisms of action. J. Agric. Food Chem. 2009, 57, 6468-6473. [CrossRef] [PubMed]

(c) 2018 by the authors. Licensee MDPI, Basel, Switzerland. This article is an open access article distributed under the terms and conditions of the Creative Commons Attribution (CC BY) license (http://creativecommons.org/licenses/by/4.0/). 